\title{
The Albanian population and migration in historic perspective
}

\begin{abstract}
In our country the first population census was conducted in 1923. After World War II, the censuses were conducted every five years and after 1960, after every ten. The last census was in 2011. During this period, Albania has passed through three stages of demographic transition: before the liberation period, the natural increase in the population was low; during the dictatorial regime, the natural increase in the population was, conversely, very high due to various measures aiming at the stimulation of the birth rate and due also to a lower mortality rate; after 1990, with the onset of democracy, the fertility rate and the mortality rate have both decreased and, therefore, the natural increase in the population is again very low. In this situation, we have seen the significant patterns of influence that population growth has on migration, family planning, etc. This article explores the development of migration in the early years after the transition as Albania introduced an international labour market following half a century of isolation.
\end{abstract}

Keywords: population, migration, economic activity, labour force, women in the labour market, industrial structure, unemployment, transition, characteristics of migrants, remittances, migration factors, socio-economic development, poverty

\section{Introduction}

In reviewing trends in the Albanian population, we can pinpoint a number of different pictures in the key moments of the country's recent history.

By the beginning of World War I, births were generally higher but, at the same time, mortality rates were also high and this was the major factor, especially due to the high rates of infant mortality and the high level of infectious diseases, which were particularly prevalent in our country, as was, without a doubt, the lack of medical services. In the aftermath of World War II, there was a large reduction in fertility and, at the same time, there was also increased mortality as a result of this war.

During the totalitarian regime, i.e. the period of 1945-1989, the total number of the population approximately tripled, with an overall increase of $138 \%$ and an average annual rate of $2.4 \%$. This happened as a result of state policies that stimulated the birth rate, while migration was strictly prohibited.

In the 1989-2001 transition period, the population has been reduced by approximately $10 \%$, with an average annual reduction of about $0.5 \%$. This population decline has occurred as a result of very large scale emigration on top of declining birth rates. 
Albania has therefore passed through three stages of demographic transition:

- before the liberation of the country, the natural increase in the overall population was small because despite a high birth rate, deaths were also higher

- during the dictatorial regime, the natural increase in the population was very high, because the birth rate was actively stimulated and mortality was low

- after 1990 and the beginning of democracy, fertility and mortality both decreased and, therefore, the natural rate of increase in the population has been very low. It is worth mentioning that, in recent years, there has been ten births per 1000 inhabitants when, before 1990, this indicator was three times greater. In terms of population growth, therefore, our country is approaching European countries.

The trends outlined here are explored in pictorial and numerical terms in Figure 1 and Tables 1 and 2, following.

\section{Figure 1 - Albanian population according to various censuses over the years}

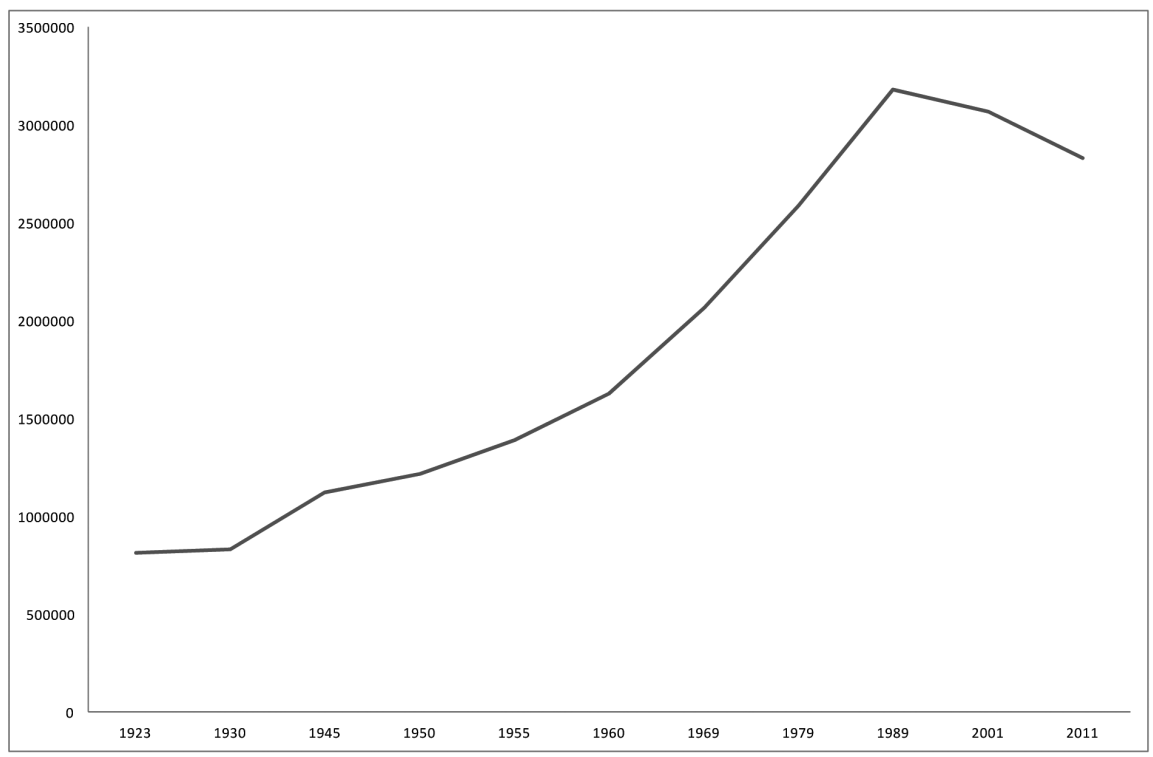

\section{Economic activity}

The Albanian population has a young age structure; consequently, a greater part of it is economically active. The large number of people of working age who have emigrated in recent years has been offset by the introduction to the labour market of cohorts of young people.

Table 3 shows the evolution of employment and unemployment between 1989 and 2005. The unemployment rate in 2005 was $22.7 \%$ of the overall labour force. From observations of the surveys conducted by INSTAT, the Albanian Institute of Statistics, 
Albania appears as one of the countries with the highest unemployment indicators in Europe.

The percentage of the total working age population (labour force plus inactive population) which is taken up by those in employment and the unemployed has fallen from $79.5 \%$ to $62.1 \%$. This decrease corresponds to an increase in the inactive population which, in 2005, reached 823156 people as against 517254 people in 1989. This trend is largely a result of the withdrawal of women from the labour market, with the proportion of the inactive female population nearly doubling in this time. The number of inactive men also increased, but to a much lesser extent, from 237362 in 1989 to 269319 in 2005.

This result is also likely to reflect a return to a traditional family model mainly in villages, after the dissolution of co-operatives and the transition from state-controlled industry.

Table 1 - The results of general censuses in Albania

\begin{tabular}{|c|c|c|c|c|c|c|}
\hline Year & Total & Male & Female & Families & $\begin{array}{c}\text { Density } \\
\text { per km }\end{array}$ & $\begin{array}{c}\text { Family } \\
\text { members }\end{array}$ \\
\hline 1923 & 814380 & 421618 & 392762 & 143065 & 29.0 & 5.7 \\
\hline 1930 & 833618 & 428959 & 404659 & 146249 & 30.3 & 5.7 \\
\hline 1945 & 1122044 & 570361 & 551683 & 196850 & 39.0 & 5.7 \\
\hline 1950 & 1218945 & 625935 & 593008 & 211613 & 42.0 & 5.8 \\
\hline 1955 & 1391499 & 713316 & 678184 & 251756 & 48.0 & 5.5 \\
\hline 1960 & 1626315 & 831294 & 795021 & 279805 & 56.6 & 5.8 \\
\hline 1969 & 2068155 & 1062931 & 1005224 & 346588 & 71.9 & 6.0 \\
\hline 1979 & 2590600 & 1337400 & 1523200 & 463333 & 90.1 & 5.6 \\
\hline 1989 & 3182417 & 1638074 & 1544343 & 675456 & 110.7 & 4.7 \\
\hline 2001 & 3069275 & 1530443 & 1538832 & 726895 & 106.7 & 4.2 \\
\hline 2011 & 2831741 & 1421810 & 1409931 & 740256 & 98.5 & 3.8 \\
\hline
\end{tabular}

Table 2 - Natural increase in the population, 1933-1940 (annual average)

\begin{tabular}{|l|c|c|}
\hline Index & In thousands of inhabitants & Per 1,000 inhabitants \\
\hline Births & 33.3 & 31.2 \\
\hline Deaths & 17.7 & 14.3 \\
\hline Natural increase & 15.6 & 16.9 \\
\hline
\end{tabular}

Source: Bërxholi, Misja and Vejsiu (1987) The Albanian Population. 
Table 3 - The economic situation of the working age population by gender (active population)

\begin{tabular}{|l|c|c|c|c|c|}
\hline Total & $\begin{array}{c}\text { Labour } \\
\text { force }\end{array}$ & $\begin{array}{c}\text { In } \\
\text { employment }\end{array}$ & Unemployed & $\begin{array}{c}\text { Unemploy- } \\
\text { ment (\%) }\end{array}$ & $\begin{array}{c}\text { Inactive } \\
\text { population }\end{array}$ \\
\hline 1989 & 1599766 & 1443167 & 156599 & 9.8 & 517254 \\
\hline 2005 & 1347281 & 1041775 & 305506 & 22.7 & 823156 \\
\hline
\end{tabular}

\begin{tabular}{|l|c|c|c|c|c|}
\hline Male & $\begin{array}{c}\text { Labour } \\
\text { force }\end{array}$ & $\begin{array}{c}\text { In } \\
\text { employment }\end{array}$ & Unemployed & $\begin{array}{c}\text { Unemploy- } \\
\text { ment (\%) }\end{array}$ & $\begin{array}{c}\text { Inactive } \\
\text { population }\end{array}$ \\
\hline 1989 & 841706 & 779271 & 62435 & 7.4 & 237362 \\
\hline 2005 & 799744 & 649646 & 150098 & 18.8 & 269319 \\
\hline
\end{tabular}

\begin{tabular}{|l|c|c|c|c|c|}
\hline Female & $\begin{array}{c}\text { Labour } \\
\text { force }\end{array}$ & $\begin{array}{c}\text { In } \\
\text { employment }\end{array}$ & Unemployed & $\begin{array}{c}\text { Unemploy- } \\
\text { ment (\%) }\end{array}$ & $\begin{array}{c}\text { Inactive } \\
\text { population }\end{array}$ \\
\hline 1989 & 758060 & 663896 & 94164 & 12.4 & 279892 \\
\hline 2005 & 547537 & 392129 & 155408 & 28.4 & 553837 \\
\hline
\end{tabular}

Source: INSTAT (2006)

The percentage of the labour force in the total population by age group

The labour force consists mainly of young people. Nearly one-half (48\%) is concentrated in the 15-34 age group. The percentage of the labour force in the 35-44 age group is $26 \%$ while the $45-54$ age group takes up $21 \%$. The over 55 s constitute only a tiny percentage of the labour force. In $2005,77.3 \%$ of the overall labour force was in employment.

\section{Industrial structure}

The most populous industrial sector is agriculture, which takes up $50.5 \%$ of the total employed population. A significant percentage is employed in construction and transportation $-12.7 \%$ - while employment in trade reaches $11.6 \%$, followed by industry with $7.1 \%$.

The districts that have the lowest proportion of their populations working in agriculture are those that appear more urbanised and industrialised than the rest of the country, such as Tirana, Durrës and Vlorë. Likewise, those districts that have the highest percentage of emigration also see the lowest proportions of people engaged in agriculture, such as Delvinë and Gjirokastër. Some districts have remained at the same level in terms of employment in agriculture, while in Lezhë, Malësia e Madhe, Pukë and Devolli, agriculture takes up more than $65 \%$ of the employed population. 
Most of those who are engaged in agriculture are self-employed (as opposed to employed by an employer), i.e. up to an extent of $71 \%$, followed by independent domestic helpers (28\%). This situation is the result of the agricultural reform which was conducted in the mid-1990s, in which land was redistributed to those families residing in rural villages.

If we look at industrial employment, we should note that this indicator reflects a distribution in some 'industries that survive', largely in mining for chromium and in oil processing. The industrial sector is mainly taken up by salaried employees, which make up about $85 \%$ of the total.

The opposite position occurs in both transport and trade, where more than $50 \%$ of employees are self-employed or are otherwise employers, followed in second place by employees. In terms of trade, we can say that this form of economic activity is organised completely in support of free market initiatives.

\section{Unemployment}

Unemployment reaches $28.4 \%$ for women and $18.8 \%$ for men. Most of the unemployed are young people.

Unemployment varies significantly from one area to another. The highest indicators of unemployment are in the northern districts of Albania, including Kukës (33.8\%); Kurbin (30.4\%) and Has (29.3\%); and in most-developed cities including Tirana $(25.3 \%)$, Vlorë $(27.2 \%)$, Shkodra $(28.0 \%)$ and Durrës $(27.0 \%)$. Unemployment is low in Gramsh (17.7\%), Kavajë (15.7\%), Lezhë (12.9\%), Lushnjë (14.9\%), Mallakastër (16\%) and Mat (17.8\%).

It is interesting to note that unemployment is higher among people who have completed high school (26.4\%) compared to those who have completed only their primary education $(22.4 \%)$. This can be explained, firstly, in that unemployment is higher among the younger generation, which includes a greater number of people with high school education than university graduates. Secondly, in rural areas, employees in agriculture have committed fewer years of schooling.

University graduates are found less frequently among the unemployed (9.5\%).

\section{Migration: the early years of the transition}

The Albanian reality today is undoubtedly that of a society in transition, which is faced with a series of socio-economic phenomena, including international migration. The legacy of a collapsing economy, the new age of the population, the high level of education, the rapid opening up to the world, the strong desire to build a democratic society and the high level of unemployment, as well as other factors, have led to a rapid growth of international migration, which has some features in common with some of the other eastern European countries with economies in transition.

In Albania after World War II, internal migration was limited while international migration almost did not exist at all. The result of developments in a series of economic, social and political factors, starting from the second half of 1990, was manifested in explosions of Albanian citizens seeking to migrate to western Europe. In July 1990, a crowd of citizens which came to about 5000 people in number were trapped in the 
headquarters of western embassies in Tirana asking to leave the country. Thanks to the intervention of the international organisations, most of them were provided with political asylum mainly in Germany, Italy and France.

At the end of 1990 and the middle of 1991, about twenty thousand Albanian nationals arrived in Greece seeking political asylum. However, conversations with representatives of the international organisations and the asylum-seekers themselves clearly showed that the exodus was not politically motivated, but reflective of a plight existing in Albania which was mainly economic in nature.

In early March 1991, a crowd of Albanian citizens were put on ships in the port of Durrës, which arrived one day later in some of the seaports of southern Italy. According to the Italian authorities, twenty thousand Albanian citizens reached Italy during this period. In early August, another exodus addressed itself to Italy. Within four days, the coast of Italy had seen an influx of large numbers of people. Italian government authorities categorically refused their admission and, on 9 August, 17000 people began the return journey on airplanes and ships. For the first time, the air route from Bari to Tirana experienced round the clock working, handling flights of civil and military aircraft which were returning migrants, and over a period of nine consecutive days.

Based on analysis conducted in March 1992 (INSTAT, 1992) the number of emigrants living abroad was 220000 , of which 200000 were over eighteen years old. After a further four months to the end of July 1992, the total number of migrants living abroad was estimated to have risen to 280000 people, while in October 1992 the total number of emigrants was put at 300000 people. The following annual publication of the Institute of Statistics estimated that about 250000 people had migrated by the end of 1992, and this figure does not include people who had gone to Greece for a few weeks or months and then come back (INSTAT, 1993).

There is no official data for the number of emigrants in later periods, a time when there are severe data fluctuations reported in the printed media. This is partly caused by there being occasionally en masse returns from Greece, one of the countries to which Albanian citizens have migrated. However, estimates related to 1995 record that the number of emigrants is about 450000 , equivalent to $14 \%$ of the country's total population, $26 \%$ of the working age population and $35 \%$ of the workforce in employment.

Comparative analysis of emigration from eastern European countries during the early transition period shows that the intensity of migration from Albania was significantly higher compared to other countries in the region. 
Table 4 - Emigration to western countries from central and eastern Europe and the former Soviet Union, 1991 to 1993

\begin{tabular}{|l|r|r|r|c|c|}
\hline \multirow{2}{*}{ Country } & \multicolumn{2}{|c|}{ Emigration (000) } & \multicolumn{3}{c|}{ Net emigration } \\
\cline { 2 - 6 } & Total & \multicolumn{1}{|c|}{ Net } & $\begin{array}{c}\text { \%o of total } \\
\text { population }\end{array}$ & $\begin{array}{c}\text { Annual } \\
\text { average (000) }\end{array}$ & $\begin{array}{c}\text { Average } \\
\text { annual per } \\
\mathbf{1 0} 000 \\
\text { inhabitants }\end{array}$ \\
\hline Albania & 400 & 300 & 9.2 & 100 & 308 \\
\hline Bulgaria & 130 & 40 & 0.4 & 13 & 14 \\
\hline Czechoslovakia & 25 & 25 & 0.2 & 8 & 5 \\
\hline Hungary & 20 & 20 & 0.2 & 7 & 7 \\
\hline Poland & 400 & 50 & 0.1 & 17 & 4 \\
\hline Romania & 500 & 175 & 0.8 & 58 & 25 \\
\hline Former Soviet Union & 1150 & 1050 & 0.4 & 350 & 13 \\
\hline Yugoslavia & 1350 & 900 & 3.7 & 300 & 126 \\
\hline Total & 3975 & 2560 & 0.7 & 853 & 20 \\
\hline
\end{tabular}

Source: Misja (1998) International migration in Albania during the transition period.

The annual average net migration per capita of the population of Albania for the three-year period 1991-1993 was approximately six times higher than the average of the Balkan countries of Yugoslavia, Bulgaria and Romania. During this period, net migration in Albania as a percentage of the total population of the country was $9.2 \%$, compared to $3.7 \%$ in Yugoslavia and $0.8 \%$ in Romania, while the average for all the countries of eastern Europe was $0.7 \%$.

Compared to these countries, the backwardness of Albania has been greater and the economic collapse deeper, while the level of wages and the real income of the population has been lower. Another factor that has strongly influenced this trend is that, in other countries of eastern Europe after World War II, international migration was partially restricted while in Albania it was almost non-existent. For Albania, the characteristic is, therefore, the introduction of explosive speed into the process of migration to the international labour market, but with a delay of nearly half a century and in conditions which were not then conducive to integration as a result of a reduced demand for labour resources in the recipient countries.

\section{Socio-demographic structures of migration}

The structure of early migrants by marital status is that $59 \%$ were single; $39 \%$ married or divorced; and $2 \%$ widowed. By gender, $73 \%$ were male and $27 \%$ female. Approximately $37 \%$ of emigrants were younger than thirty; while the average age was 28.8 years. About two-thirds of migrants were city-dwellers while one-third were from 
villages. Migrants to Greece were mainly from the southern and south-east of the country; while those to Italy came mainly from the central and coastal areas of Albania.

The structure of migrants' religious convictions showed that $73 \%$ of them were religious, while $14 \%$ were secular and $13 \%$ 'did not know'. According to the religious affiliation of migrants, $54 \%$ were Muslim; $29 \%$ Orthodox; and 17\% Catholic. Evidence of religious belief is intended to create a database from which to analyse the extent to which the values of receiving countries guaranteed the practising of the religious faith of Albanian migrants; the extent to which they were not in conflict with national legislation and universally-recognised human rights; and the potential for nondiscrimination against them in the areas of education, employment, etc.

The geographic distribution of migrants to receiving countries showed that approximately $90 \%$ of the total were located in Greece and Italy; while the rest were in countries like Germany, USA, Canada, France, Turkey, etc. Most of the early migrants were located in those countries included in the table below:

Table 5 - The main emigration countries

\begin{tabular}{|l|c|}
\hline & Number \\
\hline Belgium & 2500 \\
\hline France & 2000 \\
\hline Germany & 12000 \\
\hline Greece & 500000 \\
\hline Italy & 200000 \\
\hline Canada & 2000 \\
\hline USA & 12000 \\
\hline
\end{tabular}

Source: Ministry of Labour and Social Affairs, 2000

The identification of the socio-demographic structures of migration aims to create a store of information from which we may create an image, assumptions or estimates related to the problems of fertility; the natural increase in the population; the family situation and its socio-demographic problems; etc.

According to residential legitimacy, results showed that the majority of Albania's early emigrants were clandestine. In Italy, some $68 \%$ of migrants were thought to be living clandestinely; while in Greece the figure was probably even higher. This is the weakest point of Albanian migration. Particularly from clandestine migrants, however, are derived benefits for family members living back at home, and consequently the national economy as a whole, i.e. via remittances.

A particular interest is the identification of Albanian families that have seen one or more family members emigrate. The number of Albanian families that have one or more members in migration has been steadily increasing, and it is estimated that about one-quarter of Albanian families have one or more family members who have emigrated. 


\section{Socio-economic structures of migration}

The socio-economic characteristics of early migrants prior to migration from Albania, in terms of employment, salary, lifestyle, savings and other characteristics, reflected the difficult economic situation of that period. Indeed, this was one of the main driving factors in the migration process.

The socio-economic characteristics of migrants in the reception country (largely Greece and Italy) in terms of the sector in which migrants developed their economic activity showed that nearly $45 \%$ worked in construction and agriculture. However, significant differences were present according to the different countries: in Italy, the structure of migrants engaged in industry and tourism was, respectively, three and six times higher than in Greece; while those located in farming were nearly three times lower.

About $50 \%$ of employees had seasonal employment and more or less commuted between the seasons. In Greece, the level reached $60 \%$. Regarding the duration of the commitment to work, $58 \%$ of migrants had temporary jobs and $42 \%$ permanent ones. In analysing the level of engagement in the work done by migrants, this depended on a number of factors, of which the most important were: educational attainment; ability to speak the language of the host country; internships abroad; and the presence in the recipient country of relatives and acquaintances.

Such socio-economic structures (by economic sector, seasonal employment and duration of work) serve to emphasise that Albanian emigrants worked in sectors which were not preferred in the local economy and which did not therefore affect the level of unemployment because incomes were low (about one-third the level of local workers).

Consequently, migrants served as a buffer regulating the job market, while they did not hinder but, instead, actually contributed to the growth of national product.

\section{The reasons for migration}

In general, Albanian people are currently prone to migration, both internal and international, but international migration movements occupy the policy priority. The factors and reasons determining population movements are socio-economic in character rather than purely economic. In most cases, however, migratory flows reflect a set of causes and reasons which are much more likely to have an economic character. The group of socio-economic factors itself, spanning the entirety of the conditions of work and standards of living applying on a territory in comparison with others, classified into two major sub-groups: factors appropriate to waged labour; and the factors involved in the fulfilment of lifestyle requirements.

These migratory flows are conditioned by the needs of the economy and the distribution of labour resources, in accordance with changes in the structure of economic and territorial development. In this context, they may be analysed and addressed not as separate and independent of one another, but as related and conditional on one another, including from the perspective of the reasons for and the relationships between the varying socio-economic consequences. In the course of economic development, however, one of them is dominant. Also, there is no clear reason, because they are intertwined with each other at the same time as being differentiated. So, for example, 
in identifying the reasons for an economic migrant as the pursuit of higher income, we can also isolate this from other reasons such as 'business expansion and wealth', 'help family in hometown', etc.

Besides the reasons which have a socio-economic character, there are also noneconomic factors such as wars, political, religious and ideological frustrations and natural disasters that act in propelling migratory movements among the population.

There are three primary motives that led Albanian migrants to emigrate in the early years of the transition, based on the existence of six main reasons which have either a socio-economic character or a non-economic one, as set out in Table 6:

Table 6 - Average importance of the primary motives that led Albanians to emigrate $(\%)$

\begin{tabular}{|l|c|c|c|}
\hline Reasons & Average & Italy & Greece \\
\hline Higher wages & 29.0 & 27.4 & 30.8 \\
\hline Help family staying at home & 28.4 & 29.2 & 27.5 \\
\hline $\begin{array}{l}\text { Better working conditions (employment, } \\
\text { technological level, etc.) }\end{array}$ & 16.4 & 15.6 & 17.1 \\
\hline $\begin{array}{l}\text { Better material conditions for everyday life outside } \\
\text { of work }\end{array}$ & 17.2 & 17.2 & 17.3 \\
\hline $\begin{array}{l}\text { Material conditions for personal education or that } \\
\text { of family members }\end{array}$ & 6.0 & 7.0 & 5.0 \\
\hline Political reasons & 3.0 & 3.6 & 2.3 \\
\hline Total & 100 & 100 & 100 \\
\hline
\end{tabular}

Source: Misia (1998) International migration in Albania during the transition period.

From this data, we can draw some conclusions of which the most important is that the primary motives were (and, actually, remain) those of a directly economic character. Thus we may reach the observation, as European Commission experts have also done, that the exodus of emigrants points to them being 'People seeking to improve their economic situation'. The table sub-groups the motives for waged labour (higher wages, help family living at home and better working conditions), with these constituting $73.8 \%$ of the total motives for migration; while the sub-group dealing with lifestyle motivations (better material conditions for everyday living and conditions for education overseas) constitute $23.2 \%$ of the total motives reported.

\section{Conclusions}

The employed population of Albania has declined. This has been due to the piecemeal withdrawal of women from the labour market and a level of population growth which is flat. On the other hand, unemployment has doubled, mainly as far as younger age groups and women are concerned. 
Agriculture remains the main economic sector of the country and delivers the majority of production intended for the purposes of consumption. This has increased during the period of the transition, with $50.5 \%$ of the population occupied in it. The privatisation of housing and agricultural land has strengthened the organisation of the family as the basic unit of economic renewal, bringing with it a revival of traditional family norms.

Construction, transport, trade and public administration present a disproportionate percentage of employment, reflecting structural adjustment problems in the economy. The gaps in appropriate education and training for people working in the service sector and the lack of modern industrial production capacity remain the major problems in the labour market.

Characteristic of Albania is the rapid, and indeed explosive, introduction of an international labour market, which has been delayed for nearly half a century and, actually, in unfavourable conditions for emigration as a result of host countries' own lower demand for labour.

Nevertheless, poverty remains the main cause of migration, jointly (in some cases) with family feuds and political uncertainty. Many rural areas have become de-populated. Remittances are key to the survival of those who remain at home which is, for the most part, the elderly, young women and children. This highlights the absence of young men from most rural families.

\section{References}

Bërxholi, Arqile, Vladimir Misja and Ylli Vejsiu (1987) The Albanian Population University of Tirana.

Dalipaj, Mirela, Nicola Mai and Russell King (2003) The Myth of Migration Collapse. Analysis and Recommendations for the European Union, the United Kingdom and Albania Fabian Society and Oxfam.

Demographics Journal 2008, 2009, 2010, 2011, 2012, 2013 Tirana, Albania.

INSTAT (2001) Migration in Albania. Population and Housing Census, Tirana.

INSTAT (2001) Preliminary Results of Population and Housing Census 2001 Tirana.

INSTAT (2002) The Albanian Population. Main Results of the Population and Housing Census 2001, Institute of Statistics Tirana, Albania.

INSTAT (2011) Preliminary Results of the Census of Population and Housing 2011.

INSTAT Statistical Yearbook 1991-2001 Republic of Albania.

Lika, Eduart (2008) A Dissection of the Phenomenon of Emigration and the Role of Remittances in Albania (1991-2006), thesis, Agricultural University of Tirana.

Misja, Vladimir (1998) International migration in Albania during the transition period Marin Barleti: Tirana.

South-east European Times 2007.

UNDP (2000) Human Development Report, Albania. 